\section{Russell, Stopes and birth control}

new biography of Marie Stopes, the English birth $A$ contro1 pioneer, has recently been published. ${ }^{1}$ It relates an incident concerning Stopes and Bertrand Russell. First, however, some background is necessary to cover Russell's involvement in the birth control movement. Viscount and Lady Amberley, Bertrand Russel1's parents, were disciples and friends of John Stuart Mi11, from whom both learned to believe in birth control. (Mill was Russell's godfather.) In the 1868 general election Viscount Amberley ran as a candidate in the South Devon constituency. During this campaign it was discovered that, at a private meeting of the London Dialectical Society, he had advocated that birth control was a matter for the medical profession to consider. This let loose an onslaugh of vilification and slander. In print he was called a "filthy foul-mouthed rake" and on election day, cartoons were exhibited, accusing him of immorality, and altering his name to "Vice-count Amberley". He was defeated.

In 1890 , at the age of eighteen, Russell read Mi11's Autobiography, which had a great influence upon him. Mil1 in 1823 , at the age of seventeen, was sentenced by the Lord Mayor to fourteen days for distributing a tract on birth control. He was, however, released after a day or two, on surety of his good conduct. It was not until much later that Russell realized that, without being aware of it, he was following in his father's footsteps in regards to his religious, moral and political opinions.

In 1894 , as readers will remember from the Autobiography, Russeli and his fiancée Alys Pearsall Smith decided to marry without running the risk of having unhealthy children. Rather than abstain from sexual intercourse, they decided to use "preventatives", which is what people usual1y mean by the term "birth control"

From this time until Russel's second marriage and his

${ }^{1}$ Ruth Hall, Marie Stopes, A Biography (London: Andre Deutsch, 1977) involvement with the Society for Constructive Birth Control and Radical Progress (CBC), there is very 1ittle material on Russe11's opinions on birth control. He was, however, a staunch believer in Women's Suffrage, ${ }^{2}$ and later in People's Suffrage.

In January 1922, Russe11 and his second wife Dora attended a general meeting of the CBC. On 19 January (presumably the same day) Marie C. Stopes, the President of the CBC, wrote to Russe11:

The executive[?] committee unanimously applauded my suggestion ... that I should ask you to honour the CBC by being one of our Vice-Presidents.

Russell accepted.

A year later we find Russell in a heated public debate with Marie Stopes.

In 1923, Family Limitation, written by Margaret Sanger (an American pioneer of birth control), was published and distributed in England, by Guy and Rose Aldred. The Aldreds were prosecuted and found guilty of selling an obscene publication. Russell, as a member of the CBC, wrote to Marie Stopes, asking her help in organizing the Aldreds' appeal. He could find nothing in the pamphlet, he wrote on 13 January 1923 , which, if declared indecent, would save her own works 3 from prosecution: "I feel it important that all who stand for Birth Control should hang together, if only for the fear of hanging separately". ${ }^{4}$

Stopes not only refused to help with the Aldreds appea1, but launched a personal campaign to unhold their conviction. She stated in the March 1923 issue of the Arena:

... there has never been a prosecution in this country of the more important publications containing contraceptive knowledge. and that:

... there have been ... prosecutions of those advocating Birth Control, but in every case the prosecution has been due to some accessory objectionable feature in the method of publication or handling. (P. 8)

These statements did little to further her personal campaign for birth control.

The whole case for the prosecution rested on the fact that a policeman, acting under instructions, had written various letters to the Aldreds as publishers of Family Limitation, in the hope of obtaining copies of the pamphlet. On the first page of the pamphlet was a declaration in the

${ }^{2}$ See his "[The Status of Women]", and Thomas C. Kennedy's "The Women's Man for Wimbledon", Russell, no. 14 (summer 1974).

${ }^{3}$ Marie Stopes was the author of Married Love (1918), and with her husband, Humphrey Roe, opened the first birth control clinic in the British Empire.

${ }^{4}$ Letter to Stopes dated 13 Jan. 1923, quoted by HaIl, p. 210. 


\section{following terms:}

This booklet is supplied at the special request of

who

has declared that he or she is over twenty one years of age, and

considers the Artificial Limitation of the Family justifiable on

both individual and national grounds, and wishes to know the various

Hygienic Methods of Family Limitation and undertakes to keep it out

of the hands of unmarried persons under the age of twenty-one. ${ }^{5}$

The defendants, believing the bona fides of the supposed married man, sent the pamphlet to the policeman, without first extracting his signature to this declaration. No evidence of obscenity was given. Because no signature had been obtained, and not because the pamphlet was of an obscene nature, the Aldreds were ordered to destroy a11 copies of the pamphlet.

On 30 January 1923 , Russel1 resigned from the $C B C$ Twenty years later Marie Stopes was still justifying her actions in the Aldreds' case. On 14 May 1941, she wrote to Russe11's cousin, the Duke of Bedford:

... they were rightly prosecuted. The prosecution caused a lot of confusion in the minds of the public and led Bertrand Russell (a

careless and inaccurate and pig-headed thinker) into spreading

untrue statements in the press all over the world.

"Careless, inaccurate and pig-headed" as Russell might be, Stopes wrote to Russell of the difficulty she was having in obtaining airtime on the $\mathrm{BBC}$, and of the continued refusal of the major newspapers to print even the mildest ads or articles about her clinic. On 26 March 1953 , thirty years after Russe11 had resigned from the $C B C$, he sent Stopes a Preface to her "Evidence to the Press". A1though a review of the "Evidence" appeared only in the World's Press News, the publicity it finally received enabled Stopes to purchase ads in three of the major news papers which had hitherto blacklisted her material.

Had this cooperation between Russel1 and Stopes exist ed in the 1920s, these two intellectual and energetic pioneers of birth control, might have much sooner brought about the freedom that our present society, with women's liberation (or as I prefer to call it, people's liberation) now enjoy.

The Bertrand Russe11 Archives

Diane M. Kerss

"'The Case of Marie Stopes", Nation, Lon. (27 Jan. 1923), p. 645.

${ }^{6}$ Marie Stopes, A Biography, p. $211 \mathrm{fn}$. 